UDC: $159.9: 504$

DOI: https://doi.org/10.24195/2414-4665-2021-3-5

Inessa Vizniuk,

Doctor of Psychological Sciences, associate professor Department of Psychology and Social Work, Vinnytsia Mykhailo Kotsiubynskyi State Pedagogical University, 32, Ostrozky Str., Vinnitsia, Ukraine,

Natalia Ordatiy,

assistant of the Department of Medical Psychology and Psychiatry, Psychiatrist of the Military Medical Clinical

Center of the Central Region Vinnytsia National Pirogov Memorial Medical University, PhD student of the Department of Psychology and Social Work, Vinnytsia Mykhailo Kotsiubynskyi State Pedagogical University, 32, Ostrozky Str., Vinnytsia, Ukraine, Anatoly Ordatiy, Candidate of Medical Sciences, Lieutenant Colonel of the Medical Service of the Military Medical Clinical Center of the Central Region, 185, Kniaziv Koriatovychiv Str., Vinnytsia, Ukraine

\title{
ENVIRONMENTAL CONSCIOUSNESS OF STUDENTS IN VSPU NAMED AFTER MYKHAILO KOTSIUBYNSKYI IN THE CONDITIONS OF QUARANTINE RESTRICTIONS
}

The article considers the main problems that reflect the formation of adequate environmental awareness in people, which is now such a controversial and complex process in theoretical and practical terms, especially during the pandemic COVID-19. Modern environmental problems of today take into account, by the way, the entire sphere of human social life. The aim of the article is to study the level of anxiety of signs-states in medical students in the ecological environment of the COVID-19 pandemic in the conditions of distance learning at Vinnytsia State Pedagogical University named after Mykhailo Kotsyubynsky. The study included methods such as generalization, comparison, synthesis, concretization and the following psychodiagnostic techniques: Spilberg's State-Trait Anxiety Inventory (STAI) modified by J. Hanin, an author's questionnaire that contained 11 additional questions about online learning satisfaction. It has been empirically established that among the environmentally destructive factors that affect a person's mental health is the level of identification of the state of anxiety. The structure of pathological changes to determine the level of anxiety is dominated by mental disorders of a prenosological nature, based on a list of borderline phenomena between normal and pathology in interaction with the environment, which cause various manifestations of socio-psychological maladaptation in online learning. The conclusions indicate that the environmental friendliness of the educational environment is due to the needs of the individual in mastering the knowledge of nature and in effective coexistence with it, as well as in increasing the level of knowledge of students about the problems of its protection. The environmental education should contribute not only to the development of the course in terms of studying the discipline, but also the formation of environmental consciousness and culture of the humanistic type in order to adapt students to modern conditions.

Keywords: eco-environment, ecological factors, pandemic of COVID-19 virus, distance learning, ecological education.

Introduction and the current state of the research problem

The pandemic of the COVID-19 virus in the interpretation of human relationships with nature is primarily an environmental disaster and the devastating impact of the environment on the existence of humans. The virus has become one of the largest zoonoses, killing about 1.5 million people (the real results are likely to be made public only in a few years), or even more, people throughout the year. It is believed that its effects have led to an improvement in the eco-environment, in particular, a significant reduction in the greenhouse gas emissions, the restoration of water composition, the reduction of noise pollution, air purification and, finally, the natural regeneration of wildlife. There are also negative factors that have affected the situation in the world. These include the increase in medical and household waste, the unsystematic disposal of the personal protective equipment and, as a consequence, the aggravation of the problem of their recycling. A waste disposal during the coronavirus epidemic has become a new form of global pollution. Such notions as the introduction of the quarantine, social isolation and social distancing have contributed to an increase in the amount of household and medical waste in health care facilities by 1020 times, an increased anxiety among the population.

The whole world community is studying the problem of the impact of this virus on human's life (F. Verlanya, B. Gershunsky, M. Zhaldaka, Y. Margulis, I. Mashbytsya, I. Pidlasy, E. Polat, I. Robert, R. Norton, B. Skinner, J. Hartley, etc.), which jointly investigates its pathogenesis, behavior and global scale. It is likely that the main precondition for its emergence is the result of human activities such as deforestation, illegal animal trade and the growth of urbanization. Thus, a direct interaction with nature can cause a number of diseases that are transmitted from animals to humans. Every year there are about 3-4 infections of the indeterminate type, most of which are of the animal origin. For example, in the last few decades, about $60-70 \%$ of new human diseases of the zoonotic type appeared. The 
growth of these outbreaks is a destructive sign of the relationship between nature and human, which is becoming more complicated every year (Chen \& Olsen 2020).

Such investigators as Andrews, B., Watson, P. J., Chen, Z. J., \& Morris, R. J. (2017) argue that under quarantine restrictions, protective mechanisms are activated by mediating a maladaptive effect on students' mental health. Dagani J., Buizza C., Ferrari C., \& Ghilardi A. (2020) proposed psychometric validation on the cultural adaptation of the Italian profile of students with high anxiety in the ecoenvironment. Fierro-Suero, S., Almagro, B. J., \& SáenzLópez, P. (2020) substantiated the reliability of the equivalence questionnaire: The Two-Factor Equanimity Scale (EQUA-S) of students in the educational environment. Acquadro Maran D., \& Begotti T. (2020) revealed the anxiety of teachers in terms of emotional burnout, disconnection and their self-efficacy in the manifestation of violence in the workplace in difficult situations of increased discomfort and risk. Grub E., Wydra G., Kaefer M., \& Koellner V. (2017) disclose changes in motor balance during inpatient psychosomatic rehabilitation for health problems in a pandemic situation. Acquadro Maran, D., \& Begotti, T. (2020) reveal the essence of psychological well-being in the discussions about health care. Andrews, B., Watson, P. J., Chen, Z. J., \& Morris, R. J. (2017) reveal postmodernism as a positive psychology and post-traumatic recovery in a Christian ideological environment.

On the negative side, we can mention the fact that there is a probability of infection and the risk of communicating with carriers of the infection. It is also striking that wearing masks and a careful usage of hygiene products seems to solve the problem of personal protection, but, above all, hinders effective communication and understanding between people. In the comment to Hromadske Radio, Nina Mishchenko, the head of Fozzy Group's corporate communications department, said: "After receiving an explanation from the Ministry of Economy, vegetables and fruits in Kyiv are packed in supermarkets before weighing if a seller or buyer has a personal protective equipment." She emphasizes that everyone should keep a distance of 1.5 meters, and should limit any relationships in the personal sphere of communications in general. It is also important to study the peculiarities of remote interactions between participants in the educational process and students in the IHE during the pandemic, which is what this article is about.

\section{Aim and Tasks}

The aim of the article is to study the level of reactive and situational anxiety in students-psychologists during distance learning at Vinnytsia Mykhailo Kotsiubynskyi State Pedagogical University in the conditions of quarantine restrictions as a destructive factor of ecological consciousness of students.

The tasks of our article are to emphasize the importance of the ecological environment in terms of human life, highlight the problem of environmental friendliness in the educational environment and determine the main priorities of the human worldview on the subject of research.

\section{Research Methods}

Unfortunately, in Ukraine there are currently no thorough researches on distance learning in higher education institutions. However, it is important to take into account the personal interaction between a teacher and a student for the lack of experience during the distance learning skills for the organization of independent work and individual learning.

The spiritual degradation of a human, the limitation or curtailment of his/her worldview and demiurgic abilities are accompanied by the reorientation of the vast majority of individuals to a purely personalistic manifestation of existence, a closure on their own "Ego", self-exclusion from the direct perception of reality (Ordatiy, 2021).

In the philosophical encyclopedic dictionary edited by V. Shinkaruk ecological consciousness is noted as the highest level of mental reflection of natural and artificial environment, its inner world, reflection on the place and role of a human in the biological, physical and chemical world, as well as self-regulation of this reflection. It is characterized by all the signs of the conscious human activity, which is based on the belief that modern man is in a position of distorted perception of his/herself due to the enormous limitations of own cognitive capabilities (Philosophical encyclopedic dictionary, 2002).

The interpretation of modern ideas about the essence of the concept of "ecological consciousness" states that it is a product of human self-determination within the natural environment, which is due to a certain social consciousness that regulates this interaction through nature and self-sufficiency (Philosophical encyclopedic dictionary, 2002). The contradiction of this interaction is based on the fact that it does not seem to exist. People are accustomed to the comfort of developing natural landscapes, but given the dangerous realities of today, it is still worth overcoming the gap between the well-being of the eco-environment and human desires. The latter must understand its interference in the territorial space of the natural environment and involvement in its destruction (Fierro-Suero, Almagro, \& Sáenz-López, 2020).

Some scholars argue (G. Bateson, O. Vargo, M. Doronin, F. Cassidy, Radei, E. Rubanova, etc.) that ecological consciousness is understood as an ontological fact in the need to find optimal ways of incorporation into the collective consciousness among social groups. Sometimes this term is used in the sense of a sacred spell or mockery of the depletion of natural trajectories, over which a human is consciously harmed, in the agreement of own material security. "Nature is like mother," we usually say, but no one hears it. The whole society will suffer greatly if it does not listen to its needs. She is stronger, kinder, but stubborn and noble. We don't deserve it as children because we just forgot about gratitude. Today, Ukrainians, like most citizens of the world community, are not indifferent to the problems of environmental education, which can be observed in picture 1 (Ordatiy, 2021).

In general, the greening of society should take an enduring priority in the human mind and be as a process of mastering new ideas in the environmental and spiritual spheres and use them in the educational environment to train highly educated professionals who can withstand economic threats in all spheres of human's life. At one time V. Oskolsky noted that "it is time to consider all the priorities of modernity and activate the work of consciousness through the prism of spirituality... Economic prosperity and growth of industry are impossible in an immoral, wild, spiritless society". (Ordatiy, 2021).

Therefore, to study the features of anxiety as an indicative factor during the distance learning of students under the 
conditions of quarantine restrictions in the study are used different methods, among them we can distinguish such as analysis, systematization, synthesis, generalization, concretization, comparison and psychodiagnostic methods with the use of Psychodiagnostic Testing, Ch. Spielberg's State-Trait Anxiety Inventory (STAI) in the modification of J. Khanin, (level of identifying the state of trait anxiety) and the author's questionnaire, which contains 11 arbitrary questions about the satisfaction with distance learning.

The students of Vinnytsia Mykhailo Kotsiubynskyi State Pedagogical University, who had an online learning in the period from 22.05.2020 to 08.06.2020, were involved in the experiment. A sample of 60 students took part in the psychological experiment (65\% - 39 women and 35\% - 21 men), of whom 12 people were 1st year students, 2nd year - 14 people, 4 th year - 13 people, 5 th year - 15 people, 6 courses - 6 people), using elements of distance learning. Distance education was organized on such principles as individual orientation and accessibility of learning, providing comfortable conditions between participants in the educational process and students, taking into account individual psychological features of cognitive processes, personal learning and improving information culture etc.

Distance learning $(D L)$ is an educational process using a set of telecommunication technologies, which aims at enabling students to learn the basic amount of information they need without a direct contact with teachers in the learning process (synchronous and asynchronous forms), and which can be as an independent form of education, and in addition to another more traditional organization of education, if necessary, providing an opportunity to study the course of training, retraining or advanced training of future professionals for the necessary educational needs, without changing their usual rhythm of life (Gurevich, 2015).

It is worth mentioning that the reactive anxiety occurs in response to a specific external stressful or extreme situation (Covid-19 pandemic), which is stretched in time and is not eliminated and exacerbated by factors such as: the reality of threats to health and life, limited social contacts, the negative impact of information fields (media), etc. Situational anxiety affects the purposeful human activity, in particular, students' one in preparation for classes that are conducted online and increase reactive anxiety in the cyberspace. As a result, there is a disorganization of preparation for learning, which leads to the appearance of rapid fatigue, mistakes and reluctance to prepare for classes, a formal attitude to learning and deterioration of health. Thus, the presence of quarantine limited measures in a distance learning situation reduces the variability of rest, increases stress and anxiety (Dagani, Buizza, Ferrari, \& Ghilardi, 2020).

Distance learning was carried out with the usage of university platforms with possible access via Viber, Telegram, Facebook, Instagram, MS Teams, Zoom, Google Meet, Skype, etc. We actively used one of the available means of Internet communication named Google ClassRoom. The material for preliminary training was posted in the electronic form on the website of the university departments. Video lectures, surveys, testing, links to the material, the possibility of a free schedule of classes were used (Viznyuk, 2019).

\section{Research results}

Due to the State-Trait Anxiety Inventory by C. D. Spielberger (adapted by Y. L. Khanin), which is designed to clarify the quality of integrated self-esteem. According to the results of the method, not only psychodynamic features of personality are determined, but also its general tendencies concerning interrelation of parameters of reactivity and activity of personality. The technique helps to make a detailed and subjective description of the individual, which increases its value in psychodiagnostic terms. Its results are usually evaluated in the following gradations: up to 30 points - low; 31-45 - average; 46 and more - high anxiety. In our study, this technique was used to correlate the obtained results (on a scale of 20-80) with the ranges (quartile) of the normal distribution of students with different anxiety parameters of their activity.

According to the obtained data during the testing, the following results were (Fig. 1): the highest level of low anxiety is characteristic of 4 th year students $-84.5 \%$ (11 out of 13 respondents), for 1 st year students - 75\% (9 students out of 12), for 2 nd year students - $64.28 \%$ (9 students out of 14). The distribution among 5th and 6th year students is almost the same $46.7 \%$ and $50 \%$ (respectively among 29 women and 10 men).

Moderate anxiety has the following indicators - 5th year $40 \%$ (6 students out of 15), 6th year - 33.33\% (2 students out of $6), 2$ nd year - $28.57 \%$ (4 students out of 14$)$, 1 year - $25 \%$ (3 students out of 12), 8 women and 9 men. Indicators of high anxiety have the following distribution: for the 6th year - $16.66 \%$ (1 student out of 6 ), 5 th year - $13.33 \%$ ( 2 students out of 15 ) and for the 2nd year - $14.28 \%$ (1 student out of 14), exclusively among the female respondents, and for the 1 st year and the 4 th are not typical at all.

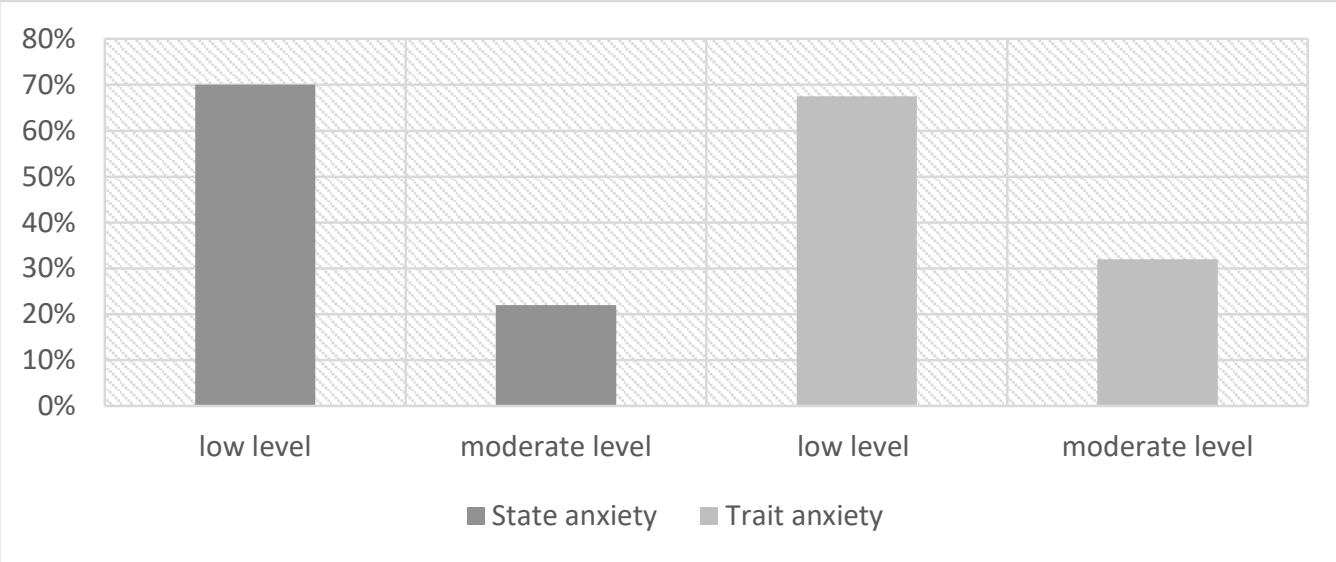

Picture 1. The level of state and trait anxiety in students of psychology on the State-Trait Anxiety Inventory by C. D. Spielberger (adapted by Y. L. Khanin) 
In picture 1 we can see that students-psychologists have a low and moderate level of both state and trait anxiety; a high level of anxiety is not observed. This indicates that students have good psycho-emotional health and psychological resilience. They do not have fears, complexes and other negative traits that have a destructive effect on the educational process. Students with increased personal anxiety usually perceive everything at their own expense. However, in our study, indicators of trait anxiety are low and moderate, and their emotional state meets the standards.

It is worth mentioning that there is a certain number of people who are satisfied with distance learning and who are interested in learning, among them $25 \%$ (15 students), while those who are not satisfied with learning - $10 \%$ (6 students out of 60). Correspondence of distance education expectations is $11.7 \%$ (7 students out of 60 ) and does not meet the expected learning outcomes - 15\% (9 students). The number of those who prepare for distance learning in time is $-35 \%$ ( 21 students out of 60 ), the rate of those who formally study (from time to time) is $15 \%$ (9 students); those who believe that they spend time in distance learning - $16.7 \%$ (10 students).

Thus, among the significant advantages of the distance learning can be noted the following: the ability to study in any case according to an individual study schedule; opportunity to study anywhere (study in hard-to-reach areas); study without separation from the main activity (study in several educational institutions simultaneously); opportunity to study in your own time distribution (unlimited time); availability of educational materials (access to the necessary literature); mobility (communication with teachers is carried out by online and offline); the distance learning during the rest; the individual approach to distance learning (Viznyuk, 2019).

During the author's questionnaire on measuring the effects of the eco-environment on the mental state of a human, we note that there were some complaints about the development of anxiety in the subjects. According to the indicators, a high number of points indicates a lack of researches dealing with environmental awareness and competence and increased anxiety, which can be seen in the following parameters:

$>$ from 0 to 10 points - indicate the optimal state of functioning of the human body and its environmental consciousness;

$>$ from 11 to 20 points - correspond to low competence for coexistence in the eco-environment in the context of the emergence of anxiety;

$>$ from 21 to 30 points - indicators of low competence in the investigation of the impact of nature on a human and, conversely, the development of anxiety in the latter under conditions of increased eco-sensations;

$>$ from 31 to 48 points - a sign of critical influence of the eco-environment on the development of anxiety in respondents.

According to the results of the survey (pictures 2-3), the students' testimonies are dominated by the tendency of the absence of any threats and fears about the existence in the natural environment as a member of an integral ecosystem (15\% - 25 people). In other cases, we observe the advantage that the eco-environment is threatening to the students in the conditions of distance learning, which contributes to the development of trait and state anxiety.

\section{I am not threatened by anything during distance learning}

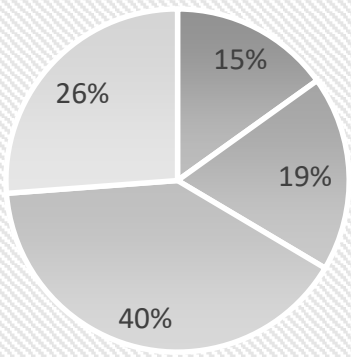

no it is not

probably so

true

really, right

\section{I am not threatened by anything during distance learning}

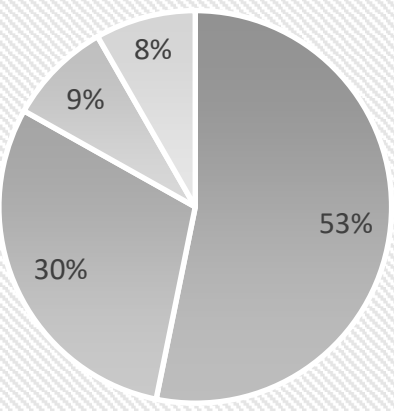

- no it is not

- probably so

- true

really, right

Pictures 2-3. Trends of preference in the subjects of the author's questionnaire 
As can be seen from picture 3 the majority of respondents (45.3\% - 29 people) still do not feel the tension in coexistence with nature (pandemic COVID-19) and satisfaction with the introduction of distance learning, observed in pictures $4-5$. In this case, the similarities between the satisfaction with distance learning and its inconsistency
(42.0\% - 25 people) are noticeable, which indicates a difference in the feelings of students against the background of the viral dominance of the epidemic. In one case, students seem to benefit from the distance in the usage of computer technology, on the other hand, they have no desire for interactive communications.

\section{It is easier to get an education during distance learning}

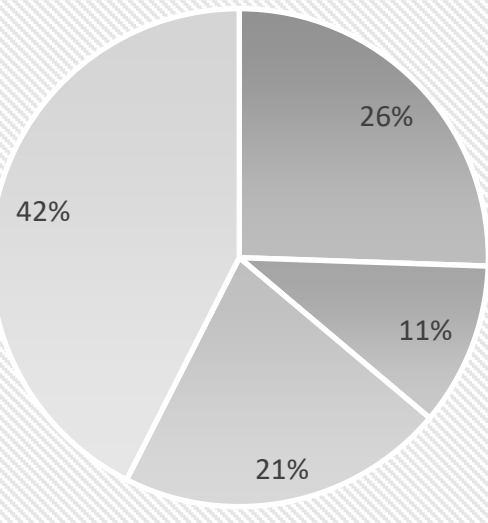

no it is not

- probably so

true

really, right

\section{It is more difficult to get an education during distance learning}

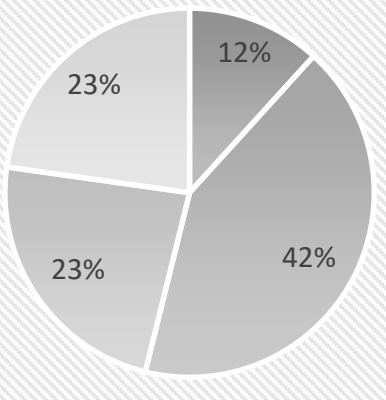

no it is not

- probably so

true

really, right

Pictures 4-5. Features of students' learning during the introduction of the distance education

After all, situational and reactive anxiety are characteristics of any of the cases, which are characterized by reduced learning potential in general. Most students have no motivation to acquire knowledge in this way and they do not care about doing an independent work. We will not describe their employment in details in the context of the distance learning - this is not the main task of the study, but will serve as a research in the future, and we will also note that the activity approach to obtaining knowledge is completely absent.

Thus, the environmental education should be understood as a process of acquiring knowledge about the nature of environmental problems, the causes of their occurrence and the possibility of solving them. It is based on the perception of the formation of environmental friendliness as a character trait, due to the understanding of coexistence with nature and the identification of their own place in its space. In terms of the environmental culture development, it would be worthwhile to create a public worldview that would normalize all the integral components of the concept of environmental policy. The leading idea of this propaganda should be the unlimited greening of social develop- ment, which will cover all spheres of human existence (Ordatiy, 2021).

\section{Discussion}

Environment-focused education must combine science and morality. Its significance for the younger generation must correspond to the future society, which can transform the traditional attempt to arm a person with new means of "conquering nature" for their own good in the direction of forming human abilities to adequately coexist with it, in the orientation of environmental realities and needs (Engel-Yeger, 2020). The reality of the relationship between a modern person and the eco-environment that corresponds to the following statement of $\mathrm{O}$. Yanitsky on the definition of "ecological culture", which means "... the nature of human relations and the environment of its existence, and in this sense... the ecological culture is part of ethics and morality: no only human's relationship with nature, not the principles of "nature protection", namely the ethical basis of the relationship between society and the environment in which it lives and which it forms. " He also provides a concise definition of the environmental culture as a values-based attitude of "a certain social subject (group, individual or commu- 
nity) to the environment of its existence: local, national, global" (Ordatiy, 2021).

Thus, society's value, but not consumers' attitude to environmental problems is the maxim of ecological culture, which will serve as a weapon against a number of anthropogenic disasters (Kaluga, 2010).

Ecological consciousness is an integral feature of personality, which is able to actively adjust their own way of life within the eco-environment, and is an important component of public consciousness and at the same time a determinant of collective worldview, which primarily contributes to rethinking the traditional attitude scale and coexistence of a human with nature in terms of socio-ecological intervention (Maksimenko, 2006). Thus, ecological consciousness is already defined by us not as a separate element of human mental activity, but as a component of modern consciousness and collective consciousness, which encourages existence in a safe eco-friendly space. The conceptual nature of human views is marked by the stability of ideas about the state of the environment, individual or collective ability to consciously and adequately understand the organic relationship between human and nature and apply on this basis environmental knowledge, skills and abilities in all areas of this symbiosis (Ordatiy, 2021).

\section{Conclusions}

Taking into account all the information mentioned, we note that the eco-environment directly surrounds people, determines their living and eating conditions, work and rest, education and upbringing. It promotes the vital activity of living beings with the environment in interaction and consistency. Thus, ecological consciousness is an integral feature of personality, which is able to actively adjust their own way of life within the eco-environment, and is an important component of public consciousness and at the same time a determinant of mass worldview, which primarily contributes to rethinking the traditional attitude scale and coexistence of human with nature in terms of socio-ecological intervention. Thus, ecological consciousness is already defined by us not as a separate element of human mental activity, but as a component of modern and mass con-

\section{References}

1. Acquadro Maran, D., \& Begotti, T. (2020). A Circle of Violence: Are Burnout, Disengagement and Self-Efficacy in Non-University Teacher Victims of Workplace Violence New and Emergent Risks? Applied Sciences, 10 (13), 4595.

DOI: https://doi.org/10.3390/app10134595 [in English].

2. Andrews, B., Watson, P. J., Chen, Z. J., \& Morris, R. J. (2017). Postmodernism, positive psychology and post-traumatic growth within a Christian ideological surround. The Journal of Positive Psychology, 12(5), 489-500. DOI: https://doi.org/10.1080/17439760.2016.1228004 [in English].

3. Chen, G., \& Olsen, J. A. (2020). Filling the psycho-social gap in the EQ-5D: the empirical support for four bolt-on dimensions. Quality of Life Research. DOI: https://doi.org/10.1007/s11136-020-02576-5 [in English].
4. Dagani, J., Buizza, C., Ferrari, C., \&

sciousness, which encourages the existence in the ecofriendly space. The conceptual nature of human views is marked by the stability of ideas about the state of the environment, individual or collective ability to consciously and adequately understand the organic relationship between a human and nature and apply on this basis environmental knowledge, skills and abilities in all areas of this symbiosis.

The state and trait anxiety are eventually characteristics of any of the cases, which are characterized by reduced learning potential in general. Most students have no motivation to acquire knowledge in this way and they do not care about doing an independent work. We will not describe their employment in details in the context of the distance learning - this is not the main task of the study, but will serve as a research in the future, and we will also note that the activity approach to obtaining knowledge is completely absent.

Distance learning has been considered to be most effective under quarantine restrictions and isolation during a coronavirus pandemic (COVID-19). The correspondence to the new realities of life the harmonious development of the individual and society and the constant transformation of values that would balance the contradictions between what society demands and what the individual needs. The reverse side of social development and progress is a state anxiety. Increasing anxiety contributes to the development of "psychological barriers" to innovation, fatigue, emotional tension, imbalance, etc., which form a disharmony of the future life path of the individual. What is more is that online learning requires increased concentration, demands and, often, exhaustion of the individual in the educational process.

However, this is not all the pathogenic consequences of the COVID-19 pandemic. Most of them we will feel in the future, but the urgency is obvious in the realization that it would be worthwhile to protect themselves from the negative effects of nature and help restore the Earth's biodiversity, which is now threatened with extinction to adequately coexist with it.

Ghilardi, A. (2020). Psychometric validation and cultural adaptation of the Italian medical student stressor questionnaire. Current Psychology. DOI: https://doi.org/10.1007/s12144-020-00922-x [in English].

5. Engel-Yeger, B. (2020). The role of poor motor coordination in predicting adults' health related quality of life. Research in Developmental Disabilities, 103, 103686.

DOI: https://doi.org/10.1016/j.ridd.2020.103686 [in English].

6. Fierro-Suero, S., Almagro, B. J., \& SáenzLópez, P. (2020). Validation of the Achievement Emotions Questionnaire for Physical Education (AEQPE). International Journal of Environmental Research and Public Health, 17(12), 4560. DOI: https://doi.org/10.3390/ijerph17124560 [in English].

7. Grub, E., Wydra, G., Kaefer, M., \& Koellner, V. (2017). Changes of Motor Balance in the Course of an Inpatient Psychosomatic Rehabilitation. Die Rehabilitation, 56(6), 389-396. DOI: 
https://doi.org/10.1055/s-0043-121279 [in English].

8. Gurevich, R. S. (2015). Formuvannia osvitnoho informatsiinoho seredovishcha dlia pidhotovki kvalifikovanykh robitnikiv $u$ profesiino-tehnichykh navchalnykh zakladakh [Formation of educational information environment for training of skilled workers in vocational schools]. (pp. 234-271). Vinnytsia: Planer LLC [in Ukrainian].

9. Kaluga, V. F. (2010). Ekolohiia svidomosti [Ecology of consciousness]. Kyiv: Millennium [in Ukrainian].

10. Maksimenko, S. D. (2006). Genezis sushchestvovaniia lichnosti [The genesis of the existence of personality]. Kyiv: Publishing house LLC "KMM" [in Ukrainian].

11. Ordatiy, N. M. (2021). Conceptual bases of Influence of Environment on Ecological Consciousness of the Person. Conference Proceedings of the 1st International Conference, September, 17, 4-9 [in English].

12. Shinkaruk, V. I., etc. (Eds.) (2002). Ekolohichna svidomist. Filosofskyi entsiklopedichnyi slovnyk [Ecological consciousness. Philosophical encyclopedic dictionary]. Kyiv: Hryhoriy Skovoroda Institute of Philosophy of the National Academy of Sciences of Ukraine: Abris [in Ukrainian].

13. Viznyuk, I. M. (2019). Vprovadzhennia PKKPT v osvitnio-informativne seredovishche distantsiinogo navchannia za programoiu «Macromedia flash» [Introduction of PKKPT in the educational and informative environment of distance learning according to the program "Macromedia flash"]. Tekhnolohii rozvitku intelektu - Technologies of intelligence development, 3 (24), 23-46. Kyiv [in Ukrainian].

\section{Література}

1. Візнюк, І. М. Впровадження ПККПТ в освітньо-інформативне середовище дистанційного навчання за програмою «Macromedia flash». Технологіi розвитку інтелекту. Київ, 2019. №3(24). С. 23-46.

2. Гуревич, Р. С. Формування освітнього інформаційного середовища для підготовки кваліфікованих робітників у професійно-технічних навчальних закладах : монографія. Вінниця : ТОВ фірма «Планер», 2015. С. 234-271.
3. Екологічна свідомість. Філософський енциклопедичний словник. В. І. Шинкарук (гол. редкол.) та ін. Київ : Інститут філософії імені Григорія Сковороди НАН України : Абрис, 2002. 742 с.

4. Калуга, В. Ф. Екологія свідомості. Київ: Міленіум, 2010. 154 с.

5. Максименко, С.Д. Генезис существования личности. Київ : Издательство ООО «КММ», 2006. $240 \mathrm{c}$.

6. Acquadro Maran D., \& Begotti T. A Circle of Violence: Are Burnout, Disengagement and SelfEfficacy in Non-University Teacher Victims of Workplace Violence New and Emergent Risks? Applied Sciences, 2020. 10(13), 4595.

7. Andrews B., Watson P. J., Chen Z. J., \& Morris R. J. Postmodernism, positive psychology and posttraumatic growth within a Christian ideological surround. The Journal of Positive Psychology, 2017. №12(5). Pp. 489-500.

8. Chen G., \& Olsen J. A. Filling the psycho-social gap in the EQ-5D: the empirical support for four bolt-on dimensions. Quality of Life Research, 2020.

9. Dagani J., Buizza C., Ferrari C., \& Ghilardi A. Psychometric validation and cultural adaptation of the Italian medical student stressor questionnaire. Current Psychology, 2020.

10.Engel-Yeger B.. The role of poor motor coordination in predicting adults' health related quality of life. Research in Developmental Disabilities, 2020. №103, 103686.

11.Fierro-Suero S., Almagro B. J., \& Sáenz-López P. Validation of the Achievement Emotions Questionnaire for Physical Education (AEQPE). International Journal of Environmental Research and Public Health, 2020. №17(12), 4560.

12.Grub E., Wydra G., Kaefer M., \& Koellner V. Changes of Motor Balance in the Course of an Inpatient Psychosomatic Rehabilitation, 2017. 56(6). Pp. 389-396.

13. Ordatiy, N. M. Conceptual bases of Influence of Environment on Ecological Consciousness of the Person. Conference Proceedings of the 1st International Conference, September. 2021. №17. P. 4-9. 
Інесса Візнюк,

доктор психологічних наук, доцент кафедри психологї та соціальної роботи Віннииького державного педагогічного університету імені Михайла Коиюбинського, вул. Острозького, 32, м. Вінниия, Україна,

Наталія Ордатій,

асистент кафедри медичної психології та психіатрії, психіатр

Військово-медичного клінічного иентру Центрального регіону Вінницького начіонального меморіального університету імені Пирогова, аспірант кафедри психології та соиіальної роботи

Вінницького державного педагогічного університету імені Михайла Коцююбинського вул. Острозького, 32, м. Вінниия, Украӥна,

ордатій Анатолій,

кандидат медичних наук, підполковник медичної служби Військово-медичного клінічного центру Центрального регіону вул. Князів Коріатовичів, 185, м. Вінничя, Украйна

\section{ЕКОЛОГІЧНА СВІДОМІСТЬ СТУДЕНТІВ}

ВДПУ ІМЕНІ МИХАЙЛА КОЦЮБИНСЬКОГО В УМОВАХ КАРАНТИННИХ ОБМЕЖЕНЬ

У статті розглянуто основні проблеми, що відображають формування у людей адекватної екологічної свідомості, що зараз є таким суперечливим і складним процесом у теоретичному та практичному суттєвому вимірах, особливо під час пандемії COVID-19. Сучасні екологічні проблеми сучасності враховують, до речі, всю сферу суспільного життя людини. Метою статті $€$ вивчення рівня тривожності ознак-станів у студентів-медиків в екологічному середовищі пандемії COVID-19 в умовах дистанційного навчання у Вінницькому державному педагогічному університеті імені Михайла Коцюбинського. Дослідження включало такі методи, як: узагальнення, порівняння, синтез і конкретизація з використанням таких психодіагностичних прийомів: Spilberg's State-Trait Anxiety Inventory (STAI) модифікований Дж. Ханіним, авторська анкета, яка містила 11 додаткових запитань про задоволеність онлайн-навчанням. Емпірично встановлено, що серед екологічно деструктивних факторів, що впливають на психічне здоров'я людини, є рівень ідентифікації стану тривоги. У структурі патологічних змін для визначення рівня тривожності переважають психічні розлади донозологічного характеру, засновані на переліку прикордонних явищ між нормою і патологією у взаємодії 3 навколишнім середовищем, які викликають різноманітні прояви соціально-психологічної дезадаптації в онлайн навчання. У висновках зазначено, що екологічність освітнього середовища зумовлена потребами особистості у оволодінні знаннями про природу та в ефективному співіснуванні з нею, а також у підвищенні рівня знань учнів про проблеми іiі охорони. Екологічна освіта має сприяти не лише розвитку курсу в частині вивчення дисципліни, а й формуванню екологічної свідомості та культури гуманістичного типу з метою адаптації студентів до сучасних умов.

Ключові слова: еко-середовище, екологічні чинники, пандемія вірусу COVID-19, дистанційне навчання, екологічна освіта. 